\title{
Moral theory and its role in everyday moral thought and action
}

Book or Report Section

Accepted Version

Hooker, B. (2018) Moral theory and its role in everyday moral thought and action. In: Zimmerman, A., Jones, K. and Timmons, M. (eds.) The Routledge Handbook on Moral Epistemology. Routledge, Oxford, UK. ISBN 9781138816121 Available at http://centaur.reading.ac.uk/75933/

It is advisable to refer to the publisher's version if you intend to cite from the work. See Guidance on citing.

Publisher: Routledge

All outputs in CentAUR are protected by Intellectual Property Rights law, including copyright law. Copyright and IPR is retained by the creators or other copyright holders. Terms and conditions for use of this material are defined in the End User Agreement. 


\section{CentAUR}

Central Archive at the University of Reading

Reading's research outputs online 


\section{Moral Theory and its Role in Everyday Moral Thought and Action Brad Hooker \\ (6843 words prior to Bibliography)}

\section{Section 1: The Meaning of "Moral" in "Moral Thought" and "Moral Theory"}

To clarify what we mean both by "moral theory" and by "everyday moral thought and action", we will need to identify what "moral" means in them. There are perennial problems with defining "moral". We want to identify a subject area with the term, but not in a way that begs questions against this or that account of the area. Let me identify what I think is the most promising line of thought, a problem with this line of thought, and then a fix for the problem.

The promising line of thought holds that what distinguishes morality from other action-guiding requirements coming from club rules, etiquette, law, and selfinterest is that morality is necessarily connected with certain reactive attitudes such as guilt, resentment, and indignation (Mill 1861: ch. 5, paragraph 14; Hart 1961, ch. 8; Sprigge 1964; Gibbard 1990: 41-8; Copp 1995: 25-6, 88-96; Wallace 1994; Darwall 2006). Negative judgments are warranted when bad decisions are made, even if those decisions are self-regarding and non-moral, but hostility to people is warranted only when they make bad moral decisions without excuse. Indeed, someone's having done something morally wrong without excuse is not only a necessary but also a sufficient condition for that person's having warranted guilt feelings and for other people's having warranted reactions of indignation or resentment towards the perpetrator. In contrast, indignation, resentment, and guilt are not necessarily appropriate when someone does something that merely goes against club rules, etiquette, law, or self-interest.

Defining morality in terms of its connection with appropriate reactive attitudes such as guilt, resentment, and indignation runs the risk of ruling out views that are recognizably theories of morality. There are recognizably moral theories that deny that feelings of guilt, resentment, and indignation are appropriate whenever someone has behaved morally wrongly without excuse. For example, there is the theory that, since guilt, resentment, and indignation are negative and destructive, these reactive attitudes should be eschewed completely. This theory might allow condemnation of morally wrong actions; what the theory rejects is directing hostility at the agents of those actions. So this theory denies that hostile reactive attitudes in response to unexcused wrong action are appropriate.

An obvious response to this line of thought is that the prospect of being the targets of feelings of guilt, resentment, or indignation can deter people from morally wrong action. Of course, being the target of feelings of guilt, resentment, or indignation can be very unpleasant. But that is why the prospect of being the targets of such feelings can deter people from doing wrong. And, we might think, the benefits to society of the deterrence easily outweigh the harms such feelings bring.

Building on that idea, some philosophers entirely instrumentalize such feelings. These philosophers propose that these feelings be structured and targeted in whatever way will do the most good. This instrumentalist line of thought, however, raises the question of whether cases can arise in which greater benefits would result from decoupling moral wrongness from feelings of guilt, resentment, and indignation. Take a case in which an agent does something 
morally wrong near the end of her life, without excuse. Arguably, her having guilt feelings, her victim's feeling resentment, and other people's feeling indignation would produce no net benefit in this case, given the immanent death of the perpetrator. Someone who thinks that feelings of guilt, resentment, and indignation wouldn't be appropriate in such a case because they would "serve no useful purpose" does not accept the necessary connection I have proposed between moral wrongness and appropriate negative reactive attitudes.

Instrumentalism about negative reactive attitudes does not hold that they are always inappropriate. Instrumentalism allows that having such attitudes will very often do some good, e.g., by punishing and thus deterring immoral behavior. So instrumentalism hardly dismisses such attitudes.

Here we need to attend to a complication. The most prominent instrumentalists about reactive attitudes have been act-consequentialists (Sidgwick 1907; Smart 1973; Parfit 1984; de Lazari-Radek and Singer 2014: 320-1, 331-5; Singer and de Lazari-Radek 2016: 198-200). Maximizing act-consequentialists believe that what makes an act right is that it produces at least as much aggregate value as any alternative act would, and that what makes an act morally wrong is that this act fails to produce as much aggregate value as some alternative act would have produced. Most act-consequentialists hold that guilt, resentment, or indignation are appropriate only when and only because occurrences of these negative attitudes result in the greatest net good-whether or not these attitudes are in response to wrong acts. This kind of actconsequentialism denies that appropriate guilt, resentment, or indignation must go hand-in-hand with judgments of wrongness.

We were considering the definition of morality in terms of its connection with appropriate reactive attitudes such as guilt, resentment, and indignation. On this definition, moral wrongness is at least necessary and often sufficient for appropriate guilt, resentment, or indignation. We can now see that one objection to this definition is that prominent act-consequentialists deny that moral wrongness is at least necessary and often sufficient for appropriate guilt, resentment, or indignation. But even these act-consequentialists admit negative reactive attitudes are very important. Whereas other theories embrace the idea that moral wrongness is a necessary and often sufficient condition for appropriate guilt, resentment, or indignation, act-consequentialism of this kind construes these reactive attitudes, not as ways of recognizing immoral behavior, but as a way of deterring it.

\section{Section 2: What is Everyday Moral Thought and Action?}

Everyday moral thought and action is a subset of everyday thought and action. Everyday thought and action are thought and action that are routine, run-of-the-mill, and unexceptional. The "everyday" should not be taken literally. Something can be an instance of everyday thought and action without there being instances of the same thought or action in literally every day. But, for something to be appropriately characterized as "everyday," it must be at least fairly frequent.

I have characterized "everyday" in a statistical way, not in an evaluative way. I do not mean to suggest that all of everyday thought is good or even permissible. There are very widespread and frequent ways of thinking and acting that are morally wrong. Discriminating against people because of their race, religion, origin, gender, or sexual orientation is an obvious example. 
Of course, if "everyday" is meant statistically, then questions about relativity arise. If Jill works in a facility for the terminally ill, dealing with people who are about to die might be routine for Jill. If Jack works in a maternity ward with a very low mortality rate, Jack probably is not regularly dealing with people who are about to die. Such variation can also occur within a single life, e.g., because of a change of jobs, having children, or taking care of an ill partner. Despite such variations, our focus in this chapter is on shared circumstances, not on differences in the circumstances different people face. So, by "everyday thought and action," I mean thought and action that are routine and unexceptional for very many people in circumstances that are routine and unexceptional for those people.

In the previous section, I defined morality in terms of its connection with appropriate reactive attitudes such as guilt, resentment, or indignation. I will now employ that definition to distinguish everyday moral thought and action from other kinds of everyday thought and action. If everyday moral thought and action go wrong without excuse, it is appropriate for the agent to feel guilt and for others to feel indignation or resentment towards the agent. If other kinds of everyday thought and action go wrong, criticizing the agent might well be appropriate (or even mandatory from teachers, coaches, or supervisors) but guilt, indignation and resentment would be inappropriate.

The reason the title of this chapter refers to thought and action is that this chapter focuses on thought meant to lead to decision and action. Sometimes moral thought consists in morally evaluating historical decisions or imaginary scenarios when the people engaged in the evaluating do not need to decide what to do. Such moral evaluation is immensely important even where there is no prospect of its resulting in action. But this chapter's focus is on moral thought leading to a decision to act or to refrain from acting.

Let me discuss some examples of everyday moral thought about what to do. In one example, you and another strong candidate are being interviewed over a few days for a job each of you very much wants. You could get away with surreptitiously spreading lies about the other candidate. Such lies would damage his chances of being given the job you want. But it never even occurs to you to spread lies about him.

Normally, at the time of decision, everyday moral thought doesn't even consider choosing to do actions of various prohibited kinds, such as physically harming an innocent person, stealing, and spreading false information about someone. Such actions are morally out of the question, at least in everyday circumstances. Hence, everyday moral thought would be wasting its time to consider them.

Let me switch to a different example. Suppose you are beside an old woman who is using a walking cane. She is not someone you know. You notice that she is about to have an accident by stepping backwards into a two-foot pothole. You can prevent the fall by immediately warning her. Or you could quietly pick her up and move her out of danger. Or you could stay still and quiet-i.e., do nothing. Or you could push her into the hole.

What would go through your mind before you decide what to do? You do not even consider pushing the woman backwards into the hole, since this is an act of a prohibited kind-physically harming her. You definitely do consider doing nothing, but you assume doing nothing would fail to prevent her accident. You also definitely do consider warning the woman in order to prevent the accident, and you assume that giving her a verbal warning would not upset her. Despite an aversion to embracing strangers, you might also consider picking her up and moving her rather than trying to warn her. But if you even consider this possibility, you immediately suspect that 
picking her up would upset her (since in effect this course of action would start out with her being grabbed by a stranger and so she might start out thinking she was being assaulted). Picking her up also runs the risk of injuring your back. Focusing on the differences among the available alternatives, your everyday moral thought plumps for giving the warning.

Relevant differences among available courses of action might be in the extent to which they would benefit others, or in the extent to which they would respect or violate others' rights, or in other ways. And available alternatives might of course differ in more than one relevant way. For example, two alternatives might differ both in their expected consequences and in the extent to which they would violate others' rights.

Often, two morally relevant differences between alternatives converge in favoring the same action. An example would be one in which the available act that would benefit others most is also the only available alternative that would avoid violating others' rights. When all the morally relevant differences between alternatives converge in their favoring the same action, everyday moral thought can proceed without hesitation to select the alternative unanimously favored.

Sometimes, even when one difference between available alternatives favors one action and another difference between alternatives favors an alternative action, everyday moral thought can move quickly. This is what happens when one difference between alternatives is obviously much less important than another. An example would be a case in which the act that would benefit others most would produce only a little larger benefit but this act would be much worse in terms of violating rights.

\section{Section 3: The Relation of Everyday Moral Thought to Moral Principles}

At the point of decision about what to do, everyday moral thought's focus on what seem to be the morally relevant differences between available alternative courses of action does not need to invoke principles. If you are choosing between only two alternative available acts $\mathrm{A}$ and $\mathrm{B}$ and there is only one relevant difference between $\mathrm{A}$ and $\mathrm{B}$ and that difference clearly favors $\mathrm{B}$, then you probably proceed immediately to do B without reference to any principle.

If you have spare time or are asked for a justification, you might take the time to formulate the principle: "when choosing between only two alternative available acts A and $\mathrm{B}$ and there is only one relevant difference between $\mathrm{A}$ and $\mathrm{B}$ and that difference clearly favors B, then proceed immediately to do B". Once such a principle is in your repertoire, you might refer to it when making decisions. But, when dealing with straightforward and obvious cases, everyday moral thought does not usually slow up to formulate or invoke principles. Everyday moral thought needs to be highly efficient, producing a more or less constant flow of decisions. In order for agents not to be stymied into indecision and inaction, everyday moral thought needs usually to be quick and at least fairly automatic.

That everyday moral thought does not usually formulate or invoke principles in easy cases does not mean that there is no place for them in the psychology of the agent engaged in everyday moral thought about easy cases. Principles might serve as unrehearsed presuppositions of decisions. What went through the agent's mind at the time of action might have been of the form "Since alternative act A has more of property $\mathrm{Z}$ than any other act I could do instead, I'll choose A". But presumably the agent must have been sensitive to actions with this property $\mathrm{Z}$ or the agent would not have taken that property to be pivotal in this case. And that sensitivity could be expressed in the form of a principle of the form "that an act has more of property $Z$ than do alternative 
acts is a reason for choosing this act". (For more on the role of moral principles in everyday moral thought and action, see Chapter 17.)

Agents do have standing sensitivities to the presence of absence of various properties of possible actions, and thus to the differences in the degree to which alternative actions have these properties. Some of these sensitivities are moral ones, e.g., concerning the rights of others, the effects on others' welfare, and so on. Having such sensitivities amounts to having dispositions to be averse to, or attracted to, acts that have the properties. At the point of making a moral decision, an agent engaged in everyday moral thought probably wouldn't mentally note the principles corresponding to the relevant dispositions. Nevertheless, everyday moral thought might be structured by dispositions to which there are corresponding principles even if these principles do not usually appear in the conscious thoughts of agents while they are engaged in everyday moral decision-making.

Everyday moral thought should run smoothly normally, but there are familiar holdups. For instance, there are plenty of cases where time is needed to ascertain relevant empirical facts. Indeed, preliminary investigation often reveals that relevant empirical facts cannot be found out, or cannot be found out without disproportionate costs in terms of time, energy, or invasion of privacy. When relevant empirical facts are not ascertainable or not ascertainable without undue costs, decisions have to be reached despite ignorance of some relevant empirical facts. There might nevertheless be available information about probabilities of this or that empirical fact. Where probabilistic information is available, everyday moral thought takes it into consideration, even if doing so complicates and shows down moral thinking.

In some cases, however, even information about probabilities isn't available. Does everyday moral thought have a "coping mechanism" for cases in which no probabilistic information is available? Tentatively, I suggest that risk aversion is wise.

Another problem that can hold up everyday moral thinking is that pause is needed to think about whether an evaluative concept applies. Would it be unkind to tell your brother the truth that his new grey beard makes him look ten years older? Would it be disloyal to correct a friend's moderate exaggeration about her achievements?

Some cases where there is a question about whether an evaluative concept can be correctly applied can be helped along by formulating and assessing different possible principles. A thought that might spring to mind in the present case is that it cannot be unkind to someone to do something to or for that person where this maximally benefits that person and was done for the sake of maximally benefiting that person. This thought is in effect a principled restriction on what can count as unkindness.

The example about disloyalty is more complicated. One might think that, if the degree of moral badness in a friend's moderate exaggeration of his or her achievements were low, then correcting the exaggeration would be disloyal. One might also think that, if the degree of moral badness were high, then correcting the exaggeration would not be disloyal. To think these things is to accept a compound principle. If one accepts this principle, then the next question is how much moral badness is in someone's moderate exaggeration of his or her achievements.

One possible answer is that the dissemination of moderately incorrect information, as long as the incorrect information is fairly harmless, is morally bad but to a low degree. Another possible answer is that the dissemination of moderately incorrect information is not morally bad as long as the person isn't aware that the information is incorrect. Yet another possible answer is that dissemination of incorrect information is very bad even if the person disseminating the information is unaware it is incorrect and even if the incorrect information is fairly harmless. Deciding which of these or other 
possible answers is correct is not relevant for the purposes of this chapter. What is relevant here is that these answers are different principles.

\section{Section 4: Problems and Questions that Lead to Moral Theorizing}

Even more importantly, trying to decide which of these principles is correct will push one into thinking about whether the moral badness in exaggeration resides simply in the false belief that can result, or in the intention to mislead, or in whatever harm is caused, or in some combination of these factors. Such reflection definitely counts as moral theorizing.

Consider now cases in which one difference between alternative available acts provides a moral reason for making one choice and at least one other difference between alternative available acts provides a not-obviously-weaker moral reason for making a different choice. Although sometimes decisions in such conflict cases must be made immediately, ideally decisions in conflict cases are instead made after careful, unhurried reflection. This kind of case is sufficiently important to warrant an extended example.

Suppose that, as a condition of taking the job you were offered, you had to sign an agreement not to undermine the authority of your boss. Now, however, you've come to see that your boss always tries to shift onto others the blame for frequent mistakes he has made, and always tries to take the credit for good ideas that actually came from others. So on one side of the conflict is the idea that honesty requires you not to lie. On the other side of the conflict is the point that, if asked a direct question about your boss's willingness to admit his mistakes and to give credit to others, there is no way for you not to undermine his authority unless you lie, since you cannot stay silent without in effect enabling others to infer the truth.

Now, if your boss had committed egregious moral wrongs, would your promise extend to covering up those wrongs? A promise which includes a commitment to cover up someone's egregious moral wrongs cannot be morally binding. Morally binding promises are nearly always restricted. For example, your boss's promise to give you a raise next year is restricted by prohibitions on his stealing money or committing fraud in order to get the extra money to pay you. Likewise, your promise not to undermine your boss's authority has limits, such as that you are not required to hide serious moral wrongs committed by your boss.

The reasoning just described seems to inch beyond everyday moral thought. The reasoning just described requires thinking about imaginary (though possible) situations. Furthermore, figuring out which such "thought experiments" are relevant requires some sophistication. And if we are explaining why certain thought experiments are relevant and others are not, we are likely to be engaging in theorizing, to at least some degree.

Perhaps the most common moral thought experiment is the one posed by the "rolereversal" question, "How would you feel if what you are considering doing to others were done to you?" One way you might reply to the role-reversal question would be, "Well, I wouldn't like such a thing to be done to me, but lots of acts are morally permissible despite the fact that people affected by of those acts don't like them. For example, although Astrid seriously considered buying Johan's house, she buys a house on the other side of town instead. Johan doesn't like Astrid's decision. But Johan's dislike of Astrid's decision is perfectly compatible with Astrid's decision being morally permissible." The implication is that the fact that someone does not like being on the receiving end of some act might not be a conclusive reason not to do that act. Reasoning from thought experiments about imaginary cases to conclusions about what does or does not make acts wrong is an instance of theorizing. 
A different reply you could give to the role-reversal question would be, "Well, while I wouldn't like such a thing's being done to me, I couldn't reasonably resent it, since I believe that the person doing such an act would be acting within his or her rights and thus I believe this person couldn't be wronging me." This reply distinguishes between what you don't like and what you reasonably resent, and implies that you cannot reasonably resent someone's treatment of you unless you think that person wronged you. Here again we find theorizing, rather than everyday moral thought.

Even more clearly than the role-reversal question, "Why?" questions pushed far enough lead to moral theory. I suggested that everyday moral thought focuses on what seem to be the morally relevant differences among available alternative acts. Now imagine children or others ask, "Why do these differences matter?" Answers to such questions typically take the shape of principles. For example, in response to the question why the difference between paying a debt and not paying it is pivotal, you answer that morality requires people to keep their promises and in particular their promises to repay loans. If asked why the difference between preventing an accident without upsetting anyone and not preventing an accident without upsetting anyone is pivotal, you might reply that people should prevent other people from having accidents (at least where this can be done with minimal effort and risk and without upsetting anyone). If asked why you didn't consider lying about your rival, you might reply that it is morally wrong to lie, and especially to lie about other people when this is detrimental to them.

To invoke such principles seems to me to step beyond everyday moral thought but this step does not in itself invoke or refer to any moral theory. However, suppose that you are pressed further, by being asked why promises should be kept or accidents prevented or malicious lies avoided. Such fairly abstract and general questions are not everyday ones (unless you are around children). Thinking about how you might answer such questions steps considerably beyond everyday moral thought. I cannot see how you can answer such questions without either confessing that you don't know or referring to some moral theory.

\section{Section 5: Moral Theory}

A moral theory is constituted by an ultimate answer to the "why?" question about moral requirements and prohibitions. For example, contractualism is the moral theory that moral requirements are determined by principles that no one could reasonably reject (Scanlon 1998; Nagel 1991; Parfit 2011, vol. 1). Rule-consequentialism is the moral theory that moral requirements are determined by rules the internalization of which by a high percentage of everyone would have unsurpassed expected value (Urmson 1953; Brandt 1967, 1979; Hooker 2000). Act-consequentialism is the theory that the ultimate moral requirement is to maximize aggregate value. And virtue ethics holds that moral requirements mirror the characteristic dispositions of a virtuous agent (Hursthouse 1999).

Each of these theories proposes that there is a one-sentence, informative answer to the question of what ultimately grounds and explains moral requirements. Admittedly, each of these theories employs concepts that need explication and clarification. On what can reasonable rejection be based? In terms of what values are consequences to be assessed? What features are necessary and sufficient for someone to be virtuous? Each of the rival one-sentence, informative answers to the "why?" question will need many pages, if not chapters, of explication and clarification.

Even with all this explication and clarification in hand, agents would not be able to apply any one of these theories without the exercise of judgment. Moral theories are 
often accused of being simplistic and mechanistic, as if they could be applied without the exercise of judgment. But the best versions of moral theories admit there are areas of complexity and subtlety and uncertainty and perhaps even indeterminacy. Definitely, no moral theory will be able to be applied comprehensively without some help from judgment (Carritt 1930: 114; Rawls 1971: 40; Shafer-Landau 1997: 601; Scanlon 1998: 199, 225, 246, 299; Blackburn 1998: 44; Crisp 2000: 29-34).

Those who are pluralists at the level of basic principles deny that there is a onesentence, monistic, informative answer to the question of what ultimately grounds moral requirements. These foundational pluralists (sometimes called Ross-style pluralists) typically maintain that there is a moral duty is to do good for others in general, another to avoid harming the innocent in various ways, another to be honest, another to be loyal (exhibit some degree of partiality) to family and friends, and so on. Foundational pluralists hold that what one is morally required to do in any particular situation is a function of the interplay of these duties. Since these foundational pluralists believe that there is no strict hierarchy in the duties, these pluralists have to turn to judgment as a means of determining when one duty outweighs others in cases of conflict (Ross 1930, 1939; Nagel 1979; McNaughton 1996; Stratton-Lake 2012; Hurka 2014: chs. 6-8).

The attraction of foundational pluralism is that the best form of it is likely to be unbeatably intuitively attractive in terms of what it ends up ruling right and wrong. The main objection to foundational pluralism is that, if there is some other theory that is equally intuitively attractive in terms of what it ends up ruling right and wrong but then goes on to supply an intuitively attractive single-principle foundation for the rest of morality, then this other theory seem more coherent than foundational pluralism. After all, theory A is more coherent than theory B if both theories are maximally consistent and comprehensive and theory A is more connected than theory B is (Sayre-McCord 1986, 1996).

\section{Section 6: The Relation of Moral Theory to Everyday Moral Thought}

Bernard Williams was one of the most influential critics of moral theory. Here is one of his most often quoted characterizations of moral theory:

Ethical theories are philosophical undertakings and commit themselves to the view that philosophy can determine, either positively or negatively, how we should think in ethics-in the negative case, to the effect that we cannot really think much at all in ethics (Williams 1985: 74).

The quotation glides smoothly from talk of ethical theories to talk about how we should think in ethics. However, the ideas constituting an ethical theory need not be prominent within the everyday moral thought that the theory recommends. I will illustrate with reference to different ethical theories, starting with the ethical theory that "philosophy can determine ... that we cannot really think much at all in ethics."

Here Williams was probably referring to some form of error theory, nihilism, or skepticism (Mackie 1977; Kalderon 2005; Olson 2014; Streumer 2017). (On these topics, see Chapters 14 and 15.) Error theory is the view that all judgments affirming the existence of this or that moral requirement or moral prohibition are in error, since moral requirements and prohibitions are merely myths. Must error theorists thus think that everyday moral thought should be abandoned? 
Well, some thinkers have provocatively contended that the world would be a better place if moral thought were jettisoned completely. However, a far more common opinion among error theorists is that moral thought is very useful and should be retained, even if in reality it is based on metaphysical error and therefore merely fictional. The most prominent form of error theory is one that (a) denies that any ethical requirements or prohibitions really exist but (b) agrees that there is a compelling pragmatic argument in favor of retaining thoughts about what is morally required, prohibited, etc. Here we have an illustration of the difference between a thesis about which basic ethical beliefs are correct and a thesis about how ethical thought should be conducted.

There are other examples of this bifurcation. The case most often discussed is actconsequentialism. Again, act-consequentialism is the theory that what makes an act morally required is that it produces more aggregate value than any alternative act would. On first considering act-consequentialism, one might think that, given its account of what makes acts morally required, act-consequentialism also tells agents to focus their everyday moral thought on calculating how much aggregate value alternative possible acts would produce. However, a few minutes of further reflection should show that actconsequentialism does not tell agents to conduct their everyday moral thought by thinking about which act would produce the greatest aggregate good. Trying to do such calculation on a case-by-case basis is likely to be highly counterproductive, as I will now explain.

Very often, agents don't have the information needed to calculate the consequences of alternative available actions. When agents don't have the information needed, they cannot do the calculations. Even when agents could obtain this information, obtaining it would take time, energy, and attention. Even when, armed with the information, agents are better able to choose the act with the best consequences, the costs of obtaining the information might outweigh the extra value produced by an optimal decision as compared with an immediate decision. Moreover, even when agents possess enough information to calculate the consequences, there is the danger of miscalculation.

Because of all these points, the consequences might be better on the whole if we don't try to calculate consequences on a case-by-case basis but instead have a more immediate and less calculating procedure for making everyday moral decisions. Whether this alternative procedure is likely to have better consequences than actconsequentialist case-by-case calculation depends on what this other procedure is. A procedure of always doing what is least expected is not likely to result in much aggregate good. What would result in more aggregate good than act-consequentialist case-by-case calculation is a procedure consisting of routinely keeping our promises and telling the truth, being loyal to our friends and family, ignoring opportunities to steal, never even considering physical aggression as a means of getting what we want, and choosing among remaining alternatives on the basis of benefits to ourselves or others. So, even those who subscribe to act-consequentialism as a theory about which acts are morally right admit that everyday moral thought should follow the procedure just described, instead of case-by-case calculation of consequences. Act-consequentialists typically hold that our moral thinking should take an act-consequentialist form only when everyday moral thought either runs into difficulty in a particular case or needs systematic reform.

Because act-consequentialism accepts that everyday moral thought should be channeled by rules, act-consequentialism and rule-consequentialism are often conflated. However, these are two different theories, with different accounts of what distinguishes between morally required and morally forbidden acts. Act- 
consequentialism is the fundamental principle that an act is morally required if and only if and because it will result in more value than any alternative act would. Rule-consequentialism is a different fundamental principle, that an act is morally required if and only if and because it is required by the code of rules whose internalization by a high percentage of everyone has unsurpassed expected value. So, although act-consequentialism and rule-consequentialism can agree about how everyday moral thought should be conducted, they disagree at the level of fundamental principle. Furthermore, there is a difference in how their fundamental principles relate to some of the concepts employed in everyday moral thought.

Before I explain this difference, I need to distinguish between traditional actconsequentialism and newer forms of act-consequentialism. Traditional actconsequentialism took the values that acts are to promote to be welfare (= well-being = utility), or welfare mixed with equality. This kind of act-consequentialism accorded no value or disvalue to acts of any kind, apart from their consequences. Newer forms of act-consequentialism allow that some kinds of act can have value or disvalue apart from their consequences, and thus that the value of a scenario can be partly determined by how many acts of these kinds are contained in the scenario (Portmore 2011). These newer forms of act-consequentialism are less distinct from non-consequentialist theories. Because of the diminished contrast between these newer forms of actconsequentialism and non-consequentialist theories, in what follows I leave out of consideration these newer forms of act-consequentialism.

According to traditional act-consequentialism, the concepts employed in everyday moral thought have a role only in the appropriate decision procedure for everyday moral thought - and not in explaining what makes acts required, permissible, or wrong. For example, traditional act-consequentialists are happy that everyday moral thought takes the difference between acts that break promises and acts that don't break promises to be an important, often pivotal, difference. But traditional act-consequentialism also holds that the fact that an act involves breaking a promise does not really count morally against the act. According to traditional act-consequentialism, the full explanation of why an act of promise breaking was wrong is that this act failed to maximize value. What is doing the explaining, according to act-consequentialism, does not mention a rule against promise breaking. Similar examples could be given involving stealing, lying, and many other kinds of act.

In contrast, rule-consequentialism insists that concepts appearing in everyday moral thought may well have a role in explaining what makes acts required, permissible, or wrong. Rule-consequentialists accept that everyday moral thought should steer people away from breaking their promises. According to rule-consequentialism, the full explanation of why an act of promise breaking was wrong is that a rule against promise breaking is one whose internalization by a high percentage of everyone has unsurpassed expected value. So what is doing the explaining mentions a rule against promise breaking. Again, similar examples could be given involving stealing, lying, physically harming the innocent, etc.

In this respect, contractualism seems to me to be very similar to ruleconsequentialism. The fundamental test that possible rules have to pass in order be selected by contractualism is different from the test that rule-consequentialism uses to select rules. That is the essential difference between contractualism and ruleconsequentialism. Nevertheless, the two theories might end up selecting very similar rules. And these rules will appear both in the everyday moral thought prescribed by the theories and in the different theories' full explanation of why this or that act is wrong. To illustrate, contractualism holds that the full explanation of why an act of (e.g.) 
stealing was wrong is that a rule against stealing is a rule that no one could reasonably reject. What is doing the explaining mentions a rule against stealing.

The most plausible forms of virtue ethics might be like contractualism and ruleconsequentialism in this regard. Virtue ethics insists that reference to the virtues is a necessary part of any full explanation of the wrongness of an act. For example, stealing is wrong because it was something an honest person would characteristically avoid, and honesty is a trait that any virtuous person would have because such a trait is good for the individual, the species, and the social group (Hursthouse 1999: 198-201).

Foundational pluralism is like contractualism and rule-consequentialism in suggesting that the concept appropriately appearing in the everyday moral thought would also appear in a full explanation of why this or that act is wrong. For example, everyday moral thought distinguishes between acts that physically harm others and acts that do not and tells us to avoid physically harming innocent people. Likewise, everyday moral thought distinguishes between promise keeping and promise breaking, between stealing and not stealing, between doing good for others and not, etc. Foundational pluralism goes on to say that these very same distinctions appear in the foundational principles of morality, and thus in full explanations of what makes acts required, permitted, or forbidden.

Again, the main difference between foundational pluralism and contractualism, ruleconsequentialism, traditional act-consequentialism, and virtue ethics is that foundational pluralism denies there is an informative unifying principle underlying the rest of morality and the other theories insist that there is an informative unifying principle, though they disagree about what it is. In this respect, foundational pluralism is unlike its rival theories. But more important to the relation of moral theory to everyday moral thought is the contrast between traditional act-consequentialism and its rival theories. Traditional act-consequentialism insists that what makes acts required or morally prohibited does not involve most of the concepts in terms of which everyday moral thought should be conducted. In that way, traditional act-consequentialism is more conceptually revisionary than are rule-consequentialism, contractualism, foundational pluralism, and virtue ethics. For the accounts of what makes acts morally required or morally forbidden that rule-consequentialism, contractualism, foundational pluralism, and virtue ethics provide employ most of the concepts in terms of which everyday moral thought should be conducted.

\section{Section 7: Conclusion}

In this chapter, I have juxtaposed the fairly quick and automatic thinking and decision making that constitutes everyday moral thought and action with the slower, more complicated, and more reflective thinking that steps beyond everyday moral thought. At the point of decision of what to do, everyday moral thought focuses on what seem to be the morally relevant differences among available alternative acts. I catalogued various difficulties that can slow down everyday moral thought. One of these was the need for greater empirical information. Slowing down everyday moral thought in the face of this need is not likely to lead to thinking about moral principles. In contrast, moral principles might well come into play when we try to tease out whether a moral concept applies. Likewise, moral principles might well come into play in thinking about cases in which one difference between alternative available acts provides a moral reason for making one choice and at least one other difference between alternative available acts provides a not-obviously-weaker moral reason for making a different choice.

Moral principles and moral theorizing even more obviously come into play when thought experiments are conducted on imaginary cases. Sometimes, imaginary cases do 
seem pivotally relevant to determining whether a possible way of responding to a very real case is morally permissible or not. A very common example of imaginary cases figuring in moral decision-making is the role-reversal thought experiment in which we contemplate how we would react if others did to us what we are considering doing to them. Reflecting on this kind of imaginary case is very likely to involve at least some moral theorizing.

Even when everyday moral thought does not run into difficult complications and is not challenged by role-reversal thought experiments, it can be challenged by the "why?" question. Pressed far enough, this question can be answered only by "I don't know" or by pointing to theses about whatever ultimately makes acts morally required, permissible, or prohibited. Theses about what ultimately makes acts morally required, permissible, or prohibited are moral theories.

In the final section of the main body of this chapter, I outlined the leading moral theories. The theories differ at the level of fundamental principle but largely agree about how everyday moral thought should be conducted. It is a mistake to assume that the content of a fundamental principle must be mirrored in the procedure for everyday moral thought. Nevertheless, the differences between acts that everyday moral thought takes to be salient involve concepts that feature in the rules or virtues that ruleconsequentialism, contractualism, foundational pluralism, and virtue ethics endorse as determining moral requirements and prohibitions. In this respect, traditional actconsequentialism is unlike those other moral theories.

\section{Bibliography}

Blackburn, S. (1998) Ruling Passions, Oxford: Clarendon Press.

Brandt, R. (1967) "Some Merits of One Form of Rule-utilitarianism," University of Colorado Studies in Philosophy: 39-65.

-_- (1979) A Theory of the Good and the Right, Oxford: Clarendon Press.

Carritt, E. F. (1930) A Theory of Morals, London: Oxford University Press.

Copp, D. (1995) Morality, Normativity, and Society, New York: Oxford University Press.

Crisp. R. (2000) "Particularizing Particularism," in B. Hooker and M. Little (eds), Moral Particularism, Oxford: Clarendon Press.

Darwall, S. (2006) The Second-Person Standpoint, Cambridge, MA: Harvard University Press.

Gibbard, A. (1990) Wise Choices, Apt Feelings, Cambridge, MA: Harvard University Press.

Hart, H. L. A. (1961) The Concept of Law, Oxford: Clarendon Press.

Hooker, B. (2000) Ideal Code, Real World: A Rule-consequentialist Theory of Morality, Oxford: Clarendon Press.

(2016) "Wrongness, Evolutionary Debunking, Public Rules," Ethica \& Politica 18: $135-49$.

Hurka, T., (2014) British Ethical Theorists from Sidgwick to Ewing, Oxford: Oxford University Press.

Hursthouse, R. (1999) On Virtue Ethics, Oxford: Clarendon Press.

Kalderon, M. (2005) Moral Fictionalism, Oxford: Clarendon Press.

de Lazari-Radek, K and Singer, P. (2014) The Point of View of the Universe: Sidgwick and Contemporary Ethics, Oxford: Oxford University Press).

Mackie, J. L. (1977) Ethics: Inventing Right and Wrong, Harmondsworth: Penguin.

McNaughton, D. (1996) “An Unconnected Heap of Duties?” Philosophical Quarterly 46: 433-47.

Mill, J. S. (1861) Utilitarianism. Frequently reprinted, e.g., in R. Crisp (ed.), Utilitarianism, Oxford: Oxford University Press, 1998. 
Nagel, T. (1979) “The Fragmentation of Value," in his Moral Questions, Cambridge:

Cambridge University Press.

- - (1991) Equality or Partiality? New York: Oxford University Press.

Olson, J. (2014) Moral Error Theory: History, Critique, Defence, Oxford: Oxford University Press.

Parfit, D. (1984) Reasons and Persons, Oxford: Clarendon Press. (2011) On What Matters, Oxford: Oxford University Press.

Portmore, D. (2011) Commonsense Consequentialism, New York: Oxford University Press.

Rawls, J. (1971) A Theory of Justice, Cambridge, MA: Harvard University Press.

Ross, W. D. (1930) The Right and the Good, Oxford: Clarendon Press.

-_- (1939) Foundations of Ethics, Oxford: Clarendon Press.

Sayer-McCord, G. (1986) "Coherence and Models for Moral Theorizing," Pacific Philosophical Quarterly 18: 170-90.

___ (1996) "Coherentist Epistemology and Moral Theory," in W. Sinnott-Armstrong and M. Timmons (eds) Moral Knowledge? New York: Oxford University Press.

Scanlon, T. M. (1998) What We Owe To Each Other, Cambridge, MA: Harvard University Press.

Shafer-Landau, R. (1997) "Moral Rules," Ethics 107: 584-611.

Sidgwick, H. (1907) Methods of Ethics, seventh edition, London: Macmillan.

Singer, P. and de Lazari-Radek, K. (2016) "Doing Our Best for Hedonistic Utilitarianism," Ethica \& Politica 18: 187-207.

Smart, J. J. C. (1973) "Outline of a System of Utilitarian Ethics" in J. J. C. Smart and Bernard Williams, Utilitarianism: For and Against, Cambridge: Cambridge University Press.

Sprigge, T. L. S. (1964) “Definition of a Moral Judgement," Philosophy 39: 301-22.

Stratton-Lake, P. (2012) "Recalcitrant Pluralism," in B. Hooker (ed.), Developing Deontology, Oxford: Blackwell Publishing.

Streumer, B. (2017) Unbelievable Errors: An Error Theory About All Normative Judgements, Oxford: Oxford University Press.

Urmson, J. O. (1953) "The Interpretation of the Moral Philosophy of J. S. Mill," Philosophical Quarterly 3: 33-9.

Wallace, R. J. (1994) Responsibility and the Moral Sentiments, Cambridge, MA: Harvard University Press

Williams, B. (1985) Ethics and the Limits of Philosophy, Cambridge, MA: Harvard University Press.

\section{Further Reading}

Griffin, J. (2015) What Can Philosophy Contribute to Ethics? Oxford: Oxford University Press. (Juxtaposes the unrealistic "Cartesian ambition" of producing a highly systematic moral theory with the insights gained from acknowledging various practicalities, including the limits of human motivation and knowledge and the role of conventional social policies.)

Hooker, B. (2012) "Theory vs Anti-Theory in Ethics," in Ulrika Heuer and Gerald Lang (eds), Luck, Value, and Commitment: Themes from the Moral Philosophy of Bernard Williams, Oxford: Oxford University Press. (Defends ethical theory against various objections, by arguing that some objections take to be unjustified what is not unjustified and other objections attribute to ethical theory commitments that ethical theory need not make.)

Timmons, M. (2013) Moral Theory, second edition, Lantham: Rowman \& Littlefield 
Publishers. (Identifies the theoretical ambition of moral theory as discovering the features that make actions morally required or morally wrong, and the practical ambition of moral theory as leading informed agents to morally right decisions and actions, and the potential conflict between these ambitions.)

Loudon, R. (1992) Morality and Moral Theory, New York: Oxford University Press, chs. 5, 7, 8. (An especially comprehensive and carefully argued discussion of the arguments for and against moral theory.) 